\title{
Treatment of osteogenesis imperfecta with intravenous pamidronate in pediatric patients: comparison between a single-day infusion twice a year protocol with other regimens described in the literature
}

\author{
S Ricart*, J Anton, M del Rio and J Ros
}

Address: Hospital Sant Joan de Deu, University of Barcelona, Barcelona, Spain

* Corresponding author

from 15th Paediatric Rheumatology European Society (PreS) Congress

London, UK. 14-17 September 2008

Published: 15 September 2008

Pediatric Rheumatology 2008, 6(SuppI I):PI33 doi:I0.I I86/I546-0096-6-SI-PI33

This abstract is available from: http://www.ped-rheum.com/content/6/SI/PI33

(c) 2008 Ricart et al; licensee BioMed Central Ltd.

\section{Background}

In 1995 our institution developed a protocol to treat children with pamidronate. Several protocols have been published to treat osteogenesis imperfecta (OI) in the last decades. Objectives: to review the usefulness of our protocol in OI and to compare it with published protocols.

\section{Materials and methods}

Retrospective review of OI patients treated with pamidronate from 1995 to 2006 in our centre. Inclusion criteria: $\mathrm{OI}<18$ years with $z$-score $<-2.5$, fractures and $z<-1$ or documented bone pain with $\mathrm{z}<-1$. Treatment: $60 \mathrm{mg}$ or $30 \mathrm{mg}$ (in prepubescents) of pamidronate every six months in a single dose.

\section{Results}

20 patients included, average length of treatment 4.1 years (range: 18 months - 8 years). Average Z-score increased from -4.3 to -2.9 after treatment and fracture rate decreased. Table 1 shows the comparison between our protocol and the ones published by Glorieux [1] and Arikoski [2].

\section{Conclusion}

Despite a lower increase in z-score in our serie, the clinical efficacy is similar to other protocols. There is a tendency towards greater gain in Z-score as the annual dosage increases.

\section{References}

I. Glorieux FH, et al: Cyclic administration of pamidronate in children with severe osteogenesis imperfecta. The New England Journal of Medicine 1998, 339:947-52.

2. Arikoski $P$, et al.: Intravenous pamidronate treatment in children with moderate to severe osteogenesis imperfecta: assessment of indices of dual-energy $\mathbf{X}$-ray absorptiometry and bone metabolic markers during the first year of therapy. Bone 2004, 34:539-46. 
Table I: Comparison between our protocol and the ones published by Glorieux and Arikoski

\begin{tabular}{llll}
\hline & HSJD & Glorieux [I] & Arikoski [2] \\
\hline Patients & 20 & 30 & 12 \\
Dose $(\mathrm{mg} / \mathrm{Kg} /$ year) & $2.4(0.3)$ & $6.8(1.1)$ & 12 \\
Periodicity of infusions $(\mathrm{m})$ & 6 & $3-4$ & 3 \\
Basal z-score & $-4.3(2)$ & $-5.3(1.2)$ & $*$ \\
Final z-score & $-3.38(2.4) * *$ & $-3.4(1.5)$ & $*$ \\
Years of treatment & $3 * *$ & $2.1($ range $1.3-5)$ & 1 \\
Mean annual increase in: z-score BMD & $0.49(0.1) 21.1(5.1)$ & $0.9541 .9(29)$ & $* 63.5(37.3)$ \\
\hline
\end{tabular}

Mean(SD). m: months. *Data not available. ** For comparability with the other series only the results of the first 3 years are shown.

Publish with Biomed Central and every scientist can read your work free of charge

"BioMed Central will be the most significant development for disseminating the results of biomedical research in our lifetime."

Sir Paul Nurse, Cancer Research UK

Your research papers will be:

- available free of charge to the entire biomedical community

- peer reviewed and published immediately upon acceptance

- cited in PubMed and archived on PubMed Central

- yours - you keep the copyright 